\title{
TTF-1 and p63 for distinguishing pulmonary small-cell carcinoma from poorly differentiated squamous cell carcinoma in previously pap-stained cytologic material
}

\author{
Neda Kalhor, Dani S Zander and Jing Liu \\ Department of Pathology and Laboratory Medicine, University of Texas Health Science Center at Houston \\ Medical School, Houston, TX, USA
}

\begin{abstract}
In histology and cell block sections, antibodies to thyroid transcription factor-1 (TTF-1) and p63 have been demonstrated to be useful markers for distinguishing between small-cell lung carcinoma and poorly differentiated pulmonary squamous cell carcinoma. In this study, we assessed the utility of TTF-1 and p63, as an antibody panel, for differentiating between these two neoplasms in previously Papanicolaou (Pap)stained cytologic smears and cytospin slides. Twenty-six lung carcinomas (13 small-cell lung carcinomas, 13 poorly differentiated pulmonary squamous cell carcinomas) were evaluated. One or two previously $95 \%$ ethanol-fixed, Pap-stained smears or cytospin slides were selected from each case. The cytologic material from these slides was transferred to positively charged slides. Unstained recuts were obtained from the corresponding histologic specimens or cell blocks. Immunohistochemical staining for TTF-1 and p63 was performed on the paired samples from each tumor. All (13/13) small-cell lung carcinomas were negative for p63 and $92 \%(12 / 13)$ were positive for TTF-1. Conversely, all (13/13) poorly differentiated pulmonary squamous cell carcinomas expressed p63 and did not express TTF-1. Immunoreactivity for p63 was also noted in bronchial reserve cells and metaplastic squamous cells. The immunostaining results obtained from the cytology slides were concordant with those of the histology or cell block sections in all cases. The results of this study show that TTF-1 and p63 immunostaining can be successfully applied to previously Pap-stained cytologic material, as an antibody panel, to facilitate pathologic differentiation between small-cell lung carcinomas and poorly differentiated pulmonary squamous cell carcinomas. p63 immunostaining, however, must be interpreted in conjunction with cytomorphology to distinguish between poorly differentiated pulmonary squamous cell carcinomas and benign cellular constituents of the lung.

Modern Pathology (2006) 19, 1117-1123. doi:10.1038/modpathol.3800629; published online 5 May 2006
\end{abstract}

Keywords: cytology; thyroid transcription factor-1 (TTF-1); p63; immunohistochemistry; carcinoma lung

Accurate distinction between small-cell and nonsmall-cell carcinomas of the lung has crucial therapeutic significance. In recent years, cytologic examinations including fine needle aspiration (FNA), bronchoscopic brushing and washing, and bronchoalveolar lavage have been increasingly used for establishing the diagnosis of lung cancer and classifying the specific tumor type. However, morphologic distinction between some small-cell lung carcinomas and nonkeratinizing poorly differen-

Correspondence: Dr J Liu, MD, PhD, Department of Pathology and Laboratory Medicine, University of Texas Health Science Center at Houston Medical School, 6431 Fannin Street, MSB 2.260, Houston, TX 77030, USA.

E-mail: jing.liu.1@uth.tmc.edu

Received 15 February 2006; revised 12 April 2006; accepted 13 April 2006; published online 5 May 2006 tiated pulmonary squamous cell carcinomas can be difficult. Cytologic features of these tumors can overlap, and a variety of superimposed degenerative and mechanical changes can distort the cytologic appearances of the tumor cells. In addition, the cytologic material may be limited in quantity and present only in direct smears or cytospin slides for evaluation. Therefore, the availability of reliable, sensitive, and specific ancillary techniques applicable to such cytologic preparations is desirable to supplement the cytomorphologic interpretation.

Thyroid transcription factor-1 (TTF-1) is a $38-\mathrm{kDa}$ member of the NKx2 family of homeodomain transcription factors. ${ }^{1}$ Numerous studies have shown it to be a sensitive marker for certain types of lung carcinoma including small-cell lung carcinoma, and to be nonimmunoreactive in pulmonary 
squamous cell carcinoma. ${ }^{2-4}$ p63, a p53-homologous nuclear protein, is expressed in most poorly differentiated pulmonary squamous cell carcinomas. ${ }^{5,6}$ TTF-1 and p63 immunostaining in histologic and cell block material is a valuable aid for separating small-cell lung carcinomas and poorly differentiated pulmonary squamous cell carcinomas. ${ }^{7-9}$ Recently, we reported that TTF-1 immunostaining can be successfully used on previously Papanicolaou (Pap)-stained cytologic material, ${ }^{10,11}$ and one other study demonstrated that p63 immunostaining can be performed to identify pulmonary squamous cell carcinomas on destained bronchoscopic cytologic specimens. ${ }^{12}$ However, these studies revealed some diagnostic limitations. The combined use of these two markers would be expected to improve diagnostic efficacy, and has not been reported in previously Pap-stained cytologic material. This study was designed to evaluate the utility of TTF-1 and p63 as a panel for differentiating between small-cell lung carcinoma and poorly differentiated pulmonary squamous cell carcinoma in 95\% ethanol-fixed previously Pap-stained direct cytologic smears and cytospin slides.

\section{Materials and methods}

\section{Study Material}

Prior to its initiation, this study was reviewed and approved by the Committee for the Protection of Human Subjects at the University of Texas Health Science Center at Houston. We reviewed our computer files for cases of small-cell lung carcinoma and poorly differentiated pulmonary squamous cell carcinoma diagnosed between 1999 and 2005, and identified 26 cases with both Pap-stained cytological slides and concurrent cell block or surgical tissue (biopsy or resection) sections from 26 different patients. Of the 26 cases, 13 were small-cell lung carcinomas and 13 were poorly differentiated pulmonary squamous cell carcinomas. The cytologic specimens included 12 computed tomography (CT)guided FNA samples and 14 bronchial brushings or washings. During the FNA and bronchial brushing procedures, direct smears were prepared and immediately fixed in 95\% ethanol. The bronchial washing material was placed in saline and slides were later prepared by cytospin method. The smears and cytospin slides were stained with the Pap technique in our laboratory. Material for cell block preparations and surgical specimens was fixed in $10 \%$ neutral buffered formalin, subjected to routine histologic processing, embedded in paraffin blocks, and stained with a routine hematoxylin-eosin stain.

For the purposes of this study, one or two original Pap-stained smears or cytospin slides were selected for immunostaining. The cytologic material from the original slides was transferred to positively charged slides using a technique previously described for transfer of cytologic material. ${ }^{10}$ From the corresponding cell block and surgical specimens, 4- $\mu \mathrm{m}-$ thick unstained recuts were obtained. Prior to immunostaining, all slides were immersed in three changes of xylene for 4 min each. The slides then underwent hydration by sequential immersion in absolute ethanol (twice), 95\% ethanol, 70\% ethanol, and water.

\section{Immunohistochemistry}

Procedures used for immunohistochemical staining of the cytologic preparations and the recut sections were identical, except that hydrogen peroxide was added to the protocol for the 95\% ethanol-fixed, Pap-stained cytologic preparations, to eliminate endogenous peroxidase activity. Primary antibodies included TTF-1 (1:60 dilution, clone 8G7G3/1; Dako Corporation, Carpinteria, CA, USA) and p63 (1:100 dilution, clone 7JUL; Novocastra Laboratories Ltd, Newcastle upon Tyne, UK). The process was initiated with application of heat-induced epitope retrieval using a steamer (Handy Steamer Plus; Black \& Decker, Shelton, CT, USA). The slides were placed in $1 \mathrm{mM}$ ethylenediamine tetraacetic acid buffer ( $\mathrm{pH} \mathrm{8)}$, steamed for $20 \mathrm{~min}$, and then allowed to cool to room temperature in the buffer for $20 \mathrm{~min}$. The Dako Autostainer (Dako) was used for the remaining steps. The cytology slides were incubated with $3 \%$ hydrogen peroxide in methanol for $20 \mathrm{~min}$ to quench any endogenous peroxidase activity. Slides were then incubated with the primary antibodies for $30 \mathrm{~min}$ at room temperature. The PowerVision $^{\mathrm{TM}}$ (ImmunoVision Technologies Co., Daly City, VA, USA) detection system was used with diaminobenzidine as the chromogen. Identically prepared cytologic smears and histologic sections of pulmonary adenocarcinoma and nonneoplastic lung tissue were used as positive controls with each staining run. Negative control slides for cytology, cell block, and surgical specimens were processed concurrently using the same staining protocol with Tris buffer substituting for the primary antibodies.

Tumors were considered to be immunopositive for TTF-1 or p63 if the tumor cells demonstrated unequivocal nuclear staining. The extensiveness of immunoreactivity was measured as a percentage of tumor cells stained. Staining intensity was graded as absent $(-)$, weak $(1+)$, moderate $(2+)$, or strong $(3+)$. The paired Student's $t$-test was used to compare the staining extensiveness between cytology and histology/cell block specimens. Differences were considered statistically significant at $P<0.05$.

\section{Results}

The mean age of the 26 patients was 63 years (range, 44-77 years). Ten patients were women and 16 were men. The diagnoses of small-cell carcinoma and 
poorly differentiated squamous cell carcinoma of pulmonary origin were made on the basis of pathologic findings (according to WHO criteria) with clinical and radiological correlation. ${ }^{13}$

The immunoreactivity (positive or negative) with TTF-1 and p63 on previously Pap-stained slides was concordant with that of corresponding histologic or cell block sections in all cases. All 13 small-cell lung carcinomas were negative for p63 and 12/13 (92\%) were positive with TTF-1 (Figure 1a-d). Conversely, all 13 poorly differentiated pulmonary squamous cell carcinomas expressed p63 and did not express TTF-1 (Figure 2a-d). In all positive cases, the antibodies yielded moderate or strong $(2+$ or $3+)$ nuclear staining intensities. Tables 1 and 2 provide details about the extensiveness of expression of each marker, which was similar in cytology and corresponding histology or cell block sections from each case. No significant differences were found by the paired Student's $t$-test for TTF-1 $(P=0.67)$ or p63 $(P=0.32)$. Necrotic, degenerating, or crushed tumor cells were negative or only weakly positive for TTF1 or p63 (Figure 3a and b).
Moderate or strong immunoreactivity for p63 was also noted in airway reserve cells and metaplastic squamous cells on both cytologic slides and histologic or cell block sections. Of 26 tumors, seven small-cell lung carcinomas and one poorly differentiated pulmonary squamous cell carcinoma contained p63-positive reserve cells (Figure 4a and b) and two of the seven small-cell lung carcinomas showed p63 positivity in metaplastic squamous cells as well (Figure 4c and d).

\section{Discussion}

Differentiating between small-cell lung carcinomas and poorly differentiated pulmonary squamous cell carcinomas can be difficult in both cytologic and histologic samples, yet has critical patient care implications. Although most small-cell lung carcinomas have more delicate cytoplasm, indistinct cell border, nuclear molding, and finer chromatin than poorly differentiated pulmonary squamous cell carcinomas, these two neoplasms can share the

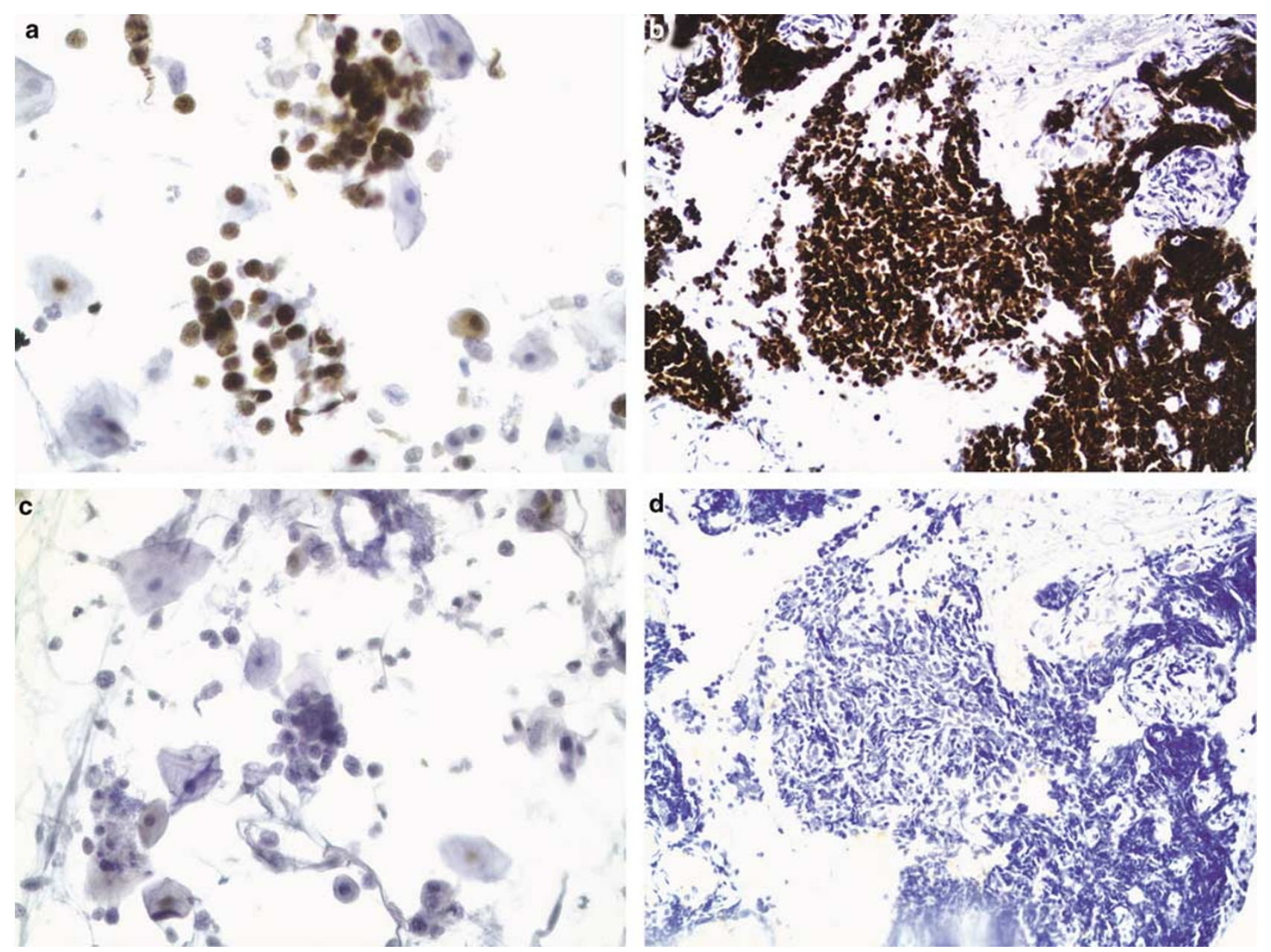

Figure 1 Small-cell lung carcinoma: (a) TTF-1 on cytologic smear $(\times 400)$; (b) TTF-1 on histologic section $(\times 200)$; (c) p63 on cytologic smear $(\times 400)$; and $(\mathbf{d})$ p63 on histologic section $(\times 200)$. 

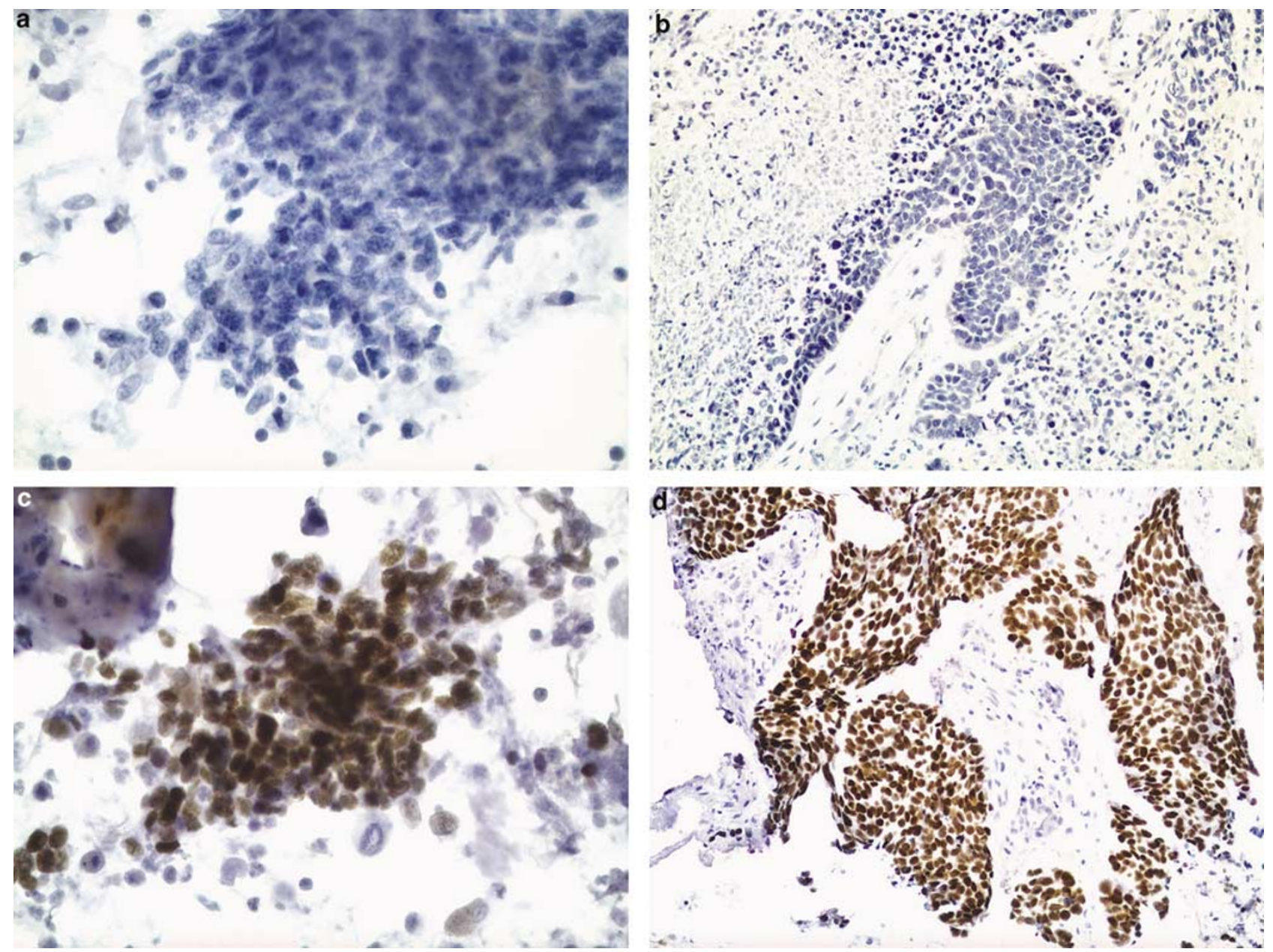

Figure 2 Poorly differentiated pulmonary squamous cell carcinoma: (a) TTF-1 on cytologic smear $(\times 400)$; (b) TTF-1 on histologic section $(\times 200)$; (c) p63 on cytologic smear $(\times 400)$; and $(\mathbf{d})$ p63 on histologic section $(\times 200)$.

Table 1 TTF-1 and p63 expression in small-cell lung carcinomas

\begin{tabular}{|c|c|c|c|c|}
\hline \multirow[t]{2}{*}{ Case } & \multicolumn{2}{|c|}{ TTF-1 (\% of tumor cells) } & \multicolumn{2}{|c|}{ p63 } \\
\hline & $\begin{array}{c}\text { On } \\
\text { previously } \\
\text { Pap-stained } \\
\text { cytologic } \\
\text { material }\end{array}$ & $\begin{array}{c}\text { On } \\
\text { unstained } \\
\text { surgical } \\
\text { tissue or cell } \\
\text { block section }\end{array}$ & $\begin{array}{c}\text { On } \\
\text { previously } \\
\text { Pap-stained } \\
\text { cytologic } \\
\text { material }\end{array}$ & $\begin{array}{c}\text { On } \\
\text { unstained } \\
\text { surgical } \\
\text { tissue or cell } \\
\text { block section }\end{array}$ \\
\hline
\end{tabular}

\begin{tabular}{ccccc}
\hline 1 & 90 & 90 & - & - \\
2 & 90 & 90 & - & - \\
3 & 90 & 90 & - & - \\
4 & 60 & 60 & - & - \\
5 & 30 & 30 & - & - \\
6 & 90 & 90 & - & - \\
7 & 90 & 90 & - & - \\
8 & 90 & 90 & - & - \\
9 & 90 & 90 & - & - \\
10 & 90 & 90 & - & - \\
11 & 80 & 100 & - & - \\
12 & - & - & - & \\
13 & 100 & 90 & - & \\
& & & &
\end{tabular}

Table 2 TTF-1 and p63 expression in poorly differentiated pulmonary squamous cell carcinomas

\begin{tabular}{|c|c|c|c|c|}
\hline \multirow[t]{2}{*}{ Case } & \multicolumn{2}{|c|}{$T T F-1$} & \multicolumn{2}{|c|}{ p63 (\% of tumor cells) } \\
\hline & $\begin{array}{c}\text { On } \\
\text { previously } \\
\text { Pap-stained } \\
\text { cytologic } \\
\text { material }\end{array}$ & $\begin{array}{c}\text { On } \\
\text { unstained } \\
\text { surgical } \\
\text { tissue or cell } \\
\text { block section }\end{array}$ & $\begin{array}{c}\text { On } \\
\text { previously } \\
\text { Pap-stained } \\
\text { cytologic } \\
\text { material }\end{array}$ & $\begin{array}{c}\text { On } \\
\text { unstained } \\
\text { surgical } \\
\text { tissue or cel } \\
\text { block sectior }\end{array}$ \\
\hline
\end{tabular}

\begin{tabular}{rllll}
\hline 1 & - & - & 90 & 95 \\
2 & - & - & 80 & 70 \\
3 & - & - & 90 & 60 \\
4 & - & - & 90 & 60 \\
5 & - & - & 90 & 90 \\
6 & - & - & 90 & 90 \\
7 & - & - & 90 & 90 \\
8 & - & - & 90 & 90 \\
9 & - & - & 80 & 90 \\
10 & - & - & 90 & 70 \\
11 & - & - & 90 & 90 \\
12 & - & - & 70 & 70 \\
13 & - & - & 70 & 90 \\
\hline
\end{tabular}

TTF-1 = thyroid $\quad$ transcription $\quad$ factor- $1 ; \quad$ Pap = Papanicolaou; $-=$ negative 

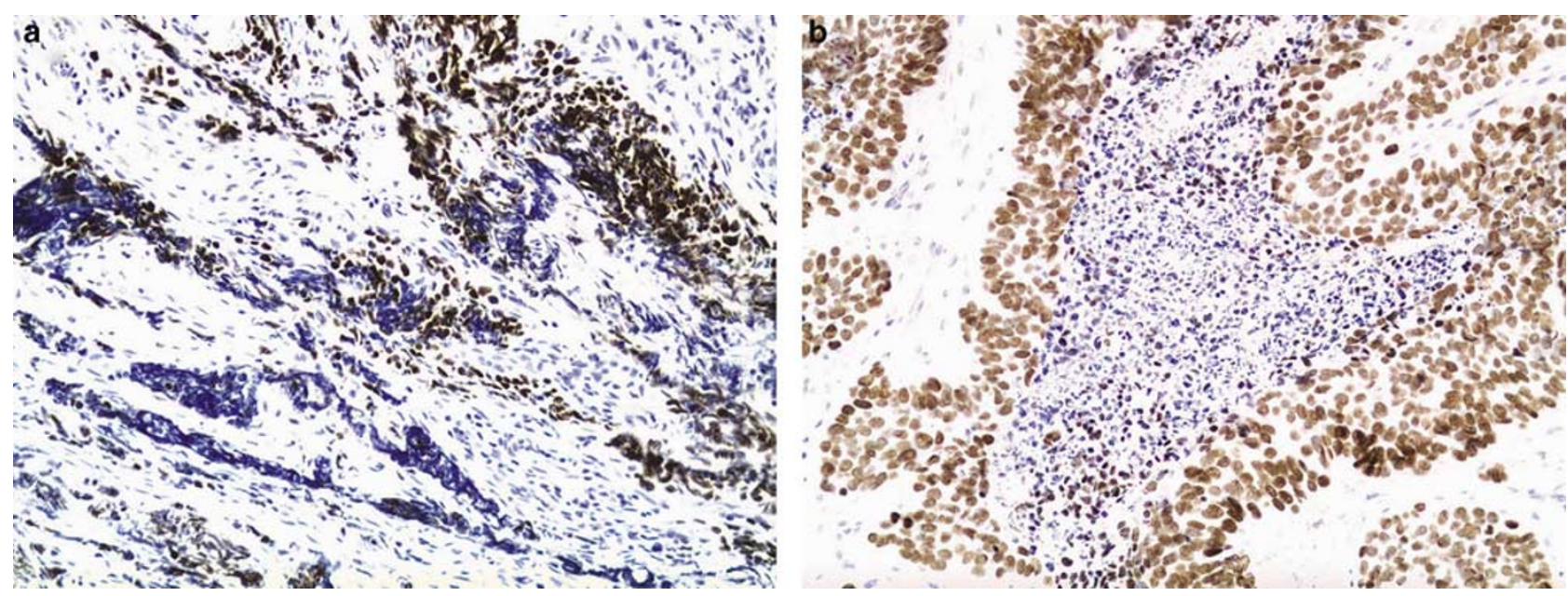

Figure 3 Conditions predisposing to loss of p63 and TTF-1 expression: (a) Areas with crush artifact in a small-cell lung carcinoma are negative for TTF-1 $(\times 200)$; and (b) immunoreactivity with p63 antibody is diminished in the necrotic tumor cells in a poorly differentiated pulmonary squamous cell carcinoma $(\times 200)$.

a

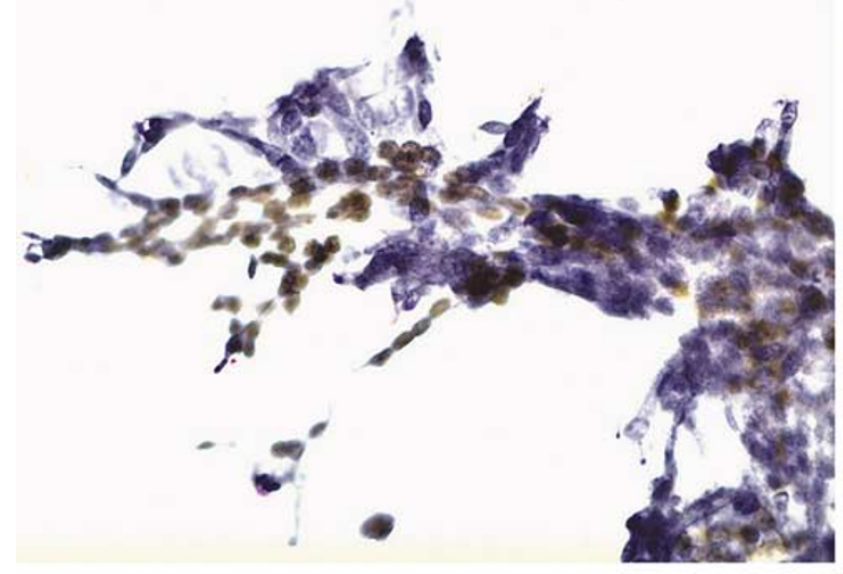

C

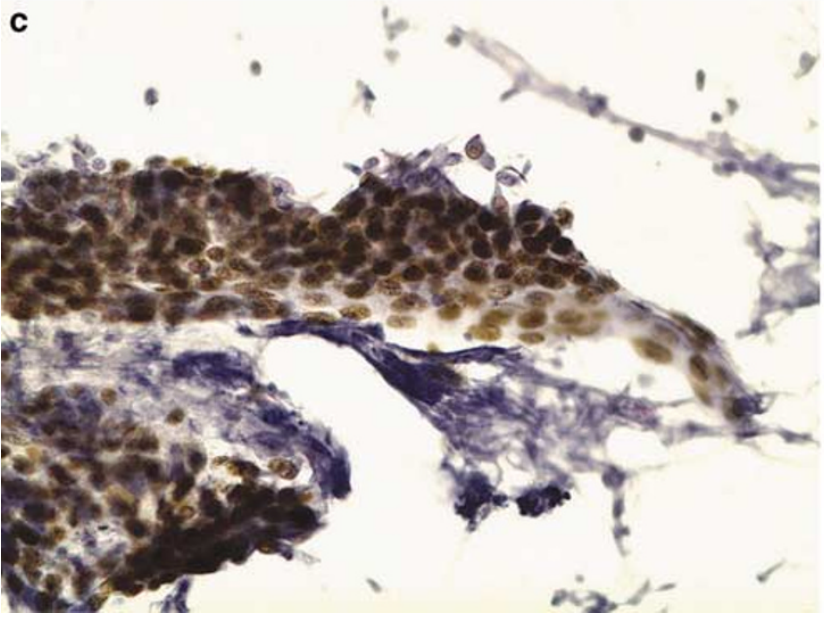

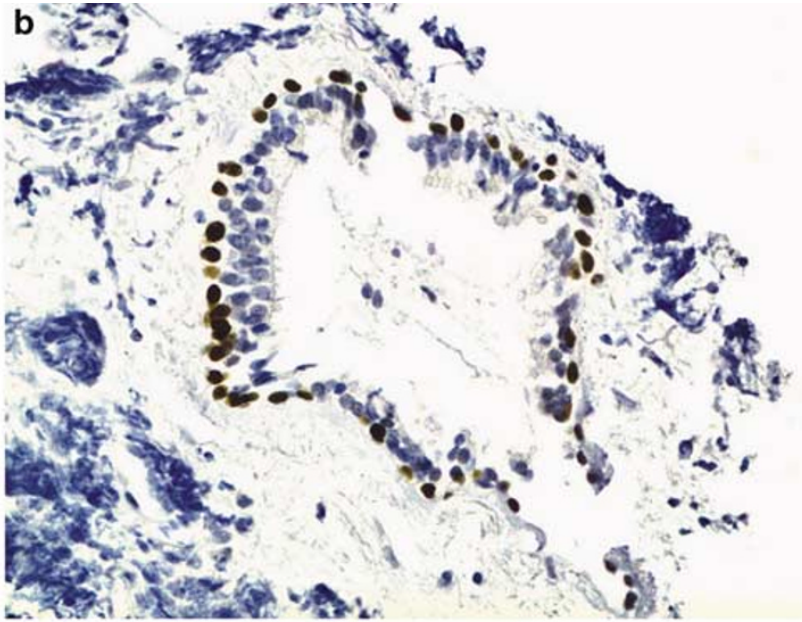

d

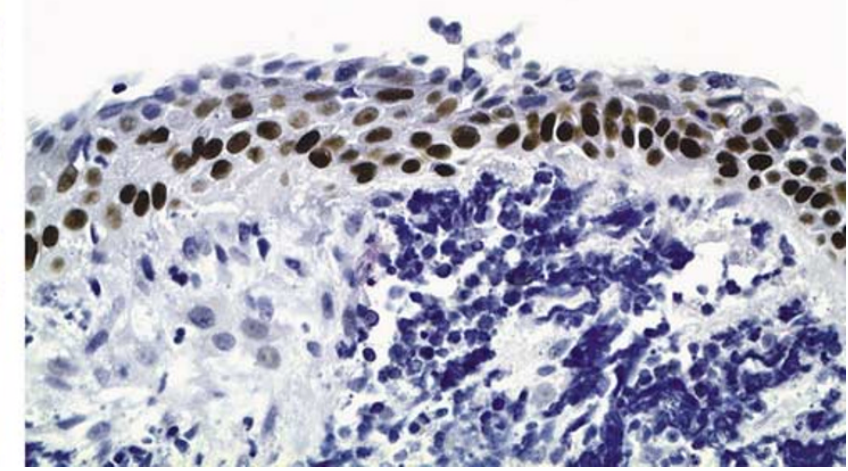

Figure 4 p63 expression by non-neoplastic cells: bronchial reserve cells (a) on cytologic smear $(\times 400)$ and $(\mathbf{b})$ on histologic section $(\times 200)$; metaplastic squamous cells $(\mathbf{c})$ on cytologic smear $(\times 400)$ and $(\mathbf{d})$ on histologic section $(\times 200)$.

morphologic features of small-cell size, scant cytoplasm, and nuclear hyperchromasia with inconspicuous nucleoli. ${ }^{14,15}$ This overlap is particular problematic for differentiating between the smallcell variant of squamous cell carcinoma and undifferentiated small-cell carcinoma. In addition, 
these tumors are subject to development of degenerative changes, necrosis, and crush artifact, all of which may obscure cellular features. Frequently, the material rendered for evaluation is relatively scant, and the pathologist is called upon to provide a definitive diagnosis from examination of a very small population of tumor cells.

Assessment of TTF-1 and p63 expression by immunohistochemistry has proven to be valuable for differentiating between small-cell lung carcinomas and poorly differentiated pulmonary squamous cell carcinomas. Previous studies on tissue or cell block sections have revealed consistently high immunoreactivity rates for TTF-1 and p63 in small-cell lung carcinomas and poorly differentiated pulmonary squamous cell carcinomas, respectively. TTF-1 is expressed in $90-100 \%$ of small-cell lung carcinomas and is essentially not detected in poorly differentiated pulmonary squamous cell carcinomas. ${ }^{2,3,16,17}$ In contrast, $90-100 \%$ of poorly differentiated pulmonary squamous cell carcinomas are immunoreactive with p63 antibody, while small-cell lung carcinomas do not express p63., ${ }^{5,6}$ The combined use of TTF-1 and p63 antibodies on tissue and cell block sections showed that the TTF-1+/p63phenotype is present in $87-94 \%$ of small-cell lung carcinomas, and the p63+/TTF- $1-$ phenotype in 96-100\% of poorly differentiated pulmonary squamous cell carcinomas. ${ }^{7-9}$

The utility of TTF-1 and p63 immunostaining on 95\% ethanol-fixed cytologic smears has rarely been reported and has been limited to a single antibody in each study. ${ }^{10-12}$ TTF-1 or p63, as a single marker, may play a limited role in differential diagnosis between small-cell lung carcinoma and poorly differentiated pulmonary squamous cell carcinoma. Using both antibodies in a panel, however, has the advantage of providing opposite patterns of positive and negative immunoreactivities for these two neoplasms. This approach may reduce the chance of incorrect interpretation due to aberrant immunoreactivities and improve diagnostic reliability. In addition, the nuclear staining pattern characteristic of both antibodies is advantageous because smallcell carcinomas and some poorly differentiated squamous cell carcinomas have scant cytoplasm. Furthermore, the nuclear staining can avoid the difficulty in separating cytoplasmic staining from background staining in cytologic slides.

The current study demonstrates that the TTF- $1+$ I p63- staining pattern was present in $92 \%$ of small-cell lung carcinomas and the TTF-1-/p63+ pattern was observed in every poorly differentiated pulmonary squamous cell carcinoma on cytologic slides and the corresponding tissue or cell block sections. The results confirm that TTF-1 and p63 immunostains can be successfully performed on cytologic material that has been previously 95\% ethanol-fixed and stained by Pap technique. These immunostaining patterns and their expression rates are consistent with those obtained from tissue and cell block sections reported in previous studies. $^{7-9}$

Although the TTF- $1+/$ p63- staining pattern supports a diagnosis of small-cell lung carcinoma, other types of pulmonary and extrapulmonary neoplasms can demonstrate the same staining results. TTF-1 is frequently expressed by pulmonary adenocarcinomas, large cell carcinomas, and neuroendocrine tumors other than small-cell lung carcinomas. ${ }^{2,4,16}$ Extrapulmonary small-cell carcinomas may also express TTF-1. ${ }^{18,19}$ For these reasons, staining results must be interpreted in the context of tumor cell morphology and clinical and radiographic information.

Likewise, our results reiterate the importance of careful morphologic assessment and clinical and radiographic correlation in the evaluation of TTF$1-/$ p63 + small cells. Pulmonary reserve cells and metaplastic squamous cells may express p63. ${ }^{20}$ p63 can also be expressed by squamous cell carcinomas originating outside the lung, as well as a variety of other carcinomas. ${ }^{21-26}$

If a neoplasm in the lung expresses neither TTF-1 nor p63 and is morphologically unclassifiable as small-cell lung carcinoma or poorly differentiated pulmonary squamous cell carcinoma, additional immunohistochemical stains may offer help. Our previous study demonstrated different patterns of expression of high molecular weight keratin and p16 in small-cell lung carcinomas and poorly differentiated pulmonary squamous cell carcinomas. ${ }^{8}$ Ninety-three percent of small-cell lung carcinomas were negative for high molecular weight keratin, but consistently showed diffuse and moderate or strong staining for p16, while $96 \%$ of poorly differentiated pulmonary squamous cell carcinomas expressed high molecular weight keratin and p16 expression varied widely in the poorly differentiated pulmonary squamous cell carcinomas. Therefore, if the differential diagnosis for a TTF-1-/p63- tumor lies between small-cell lung carcinoma and poorly differentiated pulmonary squamous cell carcinoma, staining for high molecular weight keratin suggests poorly differentiated pulmonary squamous cell carcinoma, while strong and diffuse immunoreactivity with p16 antibody favors small-cell lung carcinoma, provided that the high molecular weight keratin is negative.

In addition, tissue preservation factors can influence the immunostaining of these antibodies. In the current study as well as our previous work, we observed negative or reduced TTF-1 immunostaining in small-cell lung carcinomas with necrosis or crush artifact. ${ }^{10}$ The current study also showed decreased immunoreactivity with p63 antibody in necrotic areas of poorly differentiated pulmonary squamous cell carcinomas. In nonimmunoreactive tumors, therefore, it is important to consider the condition of the specimens in the interpretation of the immunostaining results. 
In summary, the results of this study support an extension of the use of TTF-1 and p63 immunostaining, as a panel, to previously $95 \%$ ethanol-fixed, Pap-stained cytologic material, for assistance with differentiation between small-cell lung carcinoma and poorly differentiated pulmonary squamous cell carcinoma.

\section{Acknowledgements}

We thank Pamela K Johnston, HT (ASCP), IHC, and Richard A Breckenridge, HT (ASCP), for their excellent technical support.

\section{References}

1 Hammar SP. Lung and pleural neoplasms. In: Dabbs DJ (ed). Diagnostic Immunohistochemistry. Elsevier Science, Inc.: Philadelphia, 2002, pp 267-312.

2 Kaufmann O, Dietel M. Thyroid transcription factor-1 is the superior immunohistochemical marker for pulmonary adenocarcinomas and large cell carcinomas compared to surfactant proteins A and B. Histopathology 2000;36:8-16.

3 Zamecnik J, Kodet R. Value of thyroid transcription factor-1 and surfactant apoprotein A in the differential diagnosis of pulmonary carcinomas: a study of 109 cases. Virchows Arch 2002;440:353-361.

4 Lau SK, Luthringer DJ, Eisen RN. Thyroid transcription factor-1: a review. Appl Immunohistochem Mol Morphol 2002;10:97-102.

5 Kaufmann O, Fietze E, Mengs J, et al. Value of p63 and cytokeratin 5/6 as immunohistochemical markers for the differential diagnosis of poorly differentiated and undifferentiated carcinomas. Anotomic Pathol 2001;116:823-830.

6 Wang BY, Gil J, Kaufman D, et al. p63 in pulmonary epithelium, pulmonary squamous neoplasms, and other pulmonary tumors. Hum Pathol 2002;33:921-926.

$7 \mathrm{Wu} \mathrm{M}$, Wang B, Gil J, et al. p63 and TTF-1 immunostaining. A useful marker panel for distinguishing small cell carcinoma of lung from poorly differentiated squamous cell carcinoma of lung. Am J Clin Pathol 2003;119:696-702.

8 Zhang H, Liu J, Cagle PT, et al. Distinction of pulmonary small cell carcinoma from poorly differentiated squamous cell carcinoma: an immunohistochemical approach. Mod Pathol 2005;18:111-118.

9 Wu M, Szporn AH, Zhang D, et al. Cytology applications of p63 and TTF-1 immunostaining in differential diagnosis of lung cancers. Diagn Cytopathol 2005;33: 223-227.

$10 \mathrm{Liu} \mathrm{J}$, Farhood A. Immunostaining for thyroid transcription factor-1 on fine-needle aspiration specimens of lung tumors. Cancer (Cancer Cytopathol) 2004;102: 109-114.
11 Liu J, Farhood A. Thyroid transcription factor-1 immunocytochemical staining of pleural fluid cytocentrifuge preparations for detection of small cell lung carcinoma. Acta Cytol 2004;48:635-640.

12 Shtilbans V, Szporn AH, Wu M, et al. p63 immunostaining in destained bronchoscopic cytological specimens. Diagn Cytopathol 2005;32:198-203.

13 Travis WD, Brambilla E, Muller-Hermelink HK, et al. World Health Organization Classification of Tumours: Pathology and Genetics of Tumours of the Lung, Pleura, Thymus and Heart. IARC Press: Lyon, 2004, pp 26-34.

14 Kini SR. Color Atlas of Pulmonary Cytopathology. Springer-Verlag: New York, 2002, pp 248-249.

15 DeMay RM. The Art and Science of Cytopathology. ASCP: Chicago, IL, 1996, pp 232-233.

16 Folpe AL, Gown AM, Lamps LW, et al. Thyroid transcription factor-1: immunohistochemical evaluation in pulmonary neuroendocrine tumors. Mod Pathol 1999;12:5-8.

17 Byrd-Gloster AL, Khoor A, Glass LF, et al. Differential expression of thyroid transcription factor 1 in small cell lung carcinoma and Merkel cell tumor. Hum Pathol 2000;31:58-62.

18 Ordonez NG. Value of thyroid transcription factor-1 immunostaining in distinguishing small cell lung carcinomas from other small cell carcinomas. Am J Surg Pathol 2000;24:1217-1223.

19 Agoff SN, Lamps LW, Philip AT, et al. Thyroid transcription factor-1 is expressed in extrapulmonary small cell carcinomas but not in other extrapulmonary neuroendocrine tumors. Mod Pathol 2000;13:238-242.

20 Sheikh HA, Fuhrer K, Cieply K, et al. p63 expression in assessment of bronchioloalveolar proliferations of the lung. p63 expression in assessment of bronchioloalveolar proliferations of the lung. Mod Pathol 2004;17:1134-1140.

21 Choi HR, Batsakis JG, Zhan F, et al. Differential expression of p53 gene family members p63 and p73 in head and neck squamous tumorigenesis. Hum Pathol 2002;33:158-164.

$22 \mathrm{Hu} \mathrm{H}$, Xia SH, Li AD, et al. Elevated expression of p63 protein in human esophageal squamous cell carcinomas. Int J Cancer 2002;102:580-583.

23 Wang TY, Chen BF, Yang YC, et al. Histologic and immunophenotypic classification of cervical carcinomas by expression of the p53 homologue p63: a study of 250 cases. Hum Pathol 2001;32:479-486.

24 Unger P, Ewart M, Wang BY, et al. Expression of p63 in papillary thyroid carcinoma and in Hashimoto's thyroiditis: a pathobiologic link? Hum Pathol 2003; 34:764-769.

25 Koker MM, Kleer CG. p63 expression in breast cancer: a highly sensitive and specific marker of metaplastic carcinoma. Am J Surg Pathol 2004;28:1506-1512.

26 Comperat E, Camparo P, Haus R, et al. Immunohistochemical expression of p63, p53 and MIB-1 in urinary bladder carcinoma. A tissue microarray study of 158 cases. Virchows Arch 2006;448:319-324. 